\title{
PEMANFAATAN MAC ADDRESS HOSTSPOT DALAM PENGEMBANGAN SISTEM ABSENSI GPS DALAM RANGKA MENINGKATKAN KEAKURATAN POSISI PENGGUNA
}

\author{
Fransiskus Adikara \\ Teknik Informatika, Fakultas Ilmu Komputer, Universitas Esa Unggul \\ Jalan Arjuna Utara No.9, DKI Jakarta, 11510 \\ Telp : 021- 5674223 \\ E-mail : fransiskus.adikara@esaunggul.ac.id
}

\begin{abstract}
Nowadays, most of company requires information systems for managing human resources department. Continuing previous research on GPS-based Attendance System Design (Adikara, 2013), this paper will explain about the development of the attandance system by utilizing and using the facilities of WIFI Router (Hotspot) to get user's placemarks in the multi-storey building. The system sends the MAC address of WIFI Router (Hotspot) as user location. The objectives is the implementation to get MAC addresses of WiFi routers on Android 4.x operating system and combined with GPS-based attendance system for attendance systems development. The study was conducted by using Extreme Programming method in software development process. The attendance system results show that the smartphone based Android operating system can use and apply the GPS technology and the MAC address detection in order to keep an accurate user's location. These systems development sustainability is also developing a system more credible check-in facility, for example by adding a biometric scanner facilities for its users.
\end{abstract}

\section{Abstrak}

Sistem untuk mengelola informasi sumber daya manusia yang ada di dalam perusahaan sangatlah dibutuhkan oleh perusahaan. Melanjutkan penelitian sebelumnya mengenai perancangan sistem absensi berbasis GPS (Adikara, 2013), maka akan dilakukan pengembangan sistem tersebut dengan pemanfaat teknologi lainnya sebagai penanda letak dari karyawan tersebut di dalam gedung bertingkat, yaitu menggunakan fasilitas WIFI Router (Hotspot) untuk kemudian mengirimkan MAC Address dari WIFI Router (Hotspot) tersebut. Tujuan yang ingin dicapai adalah pengaplikasian MAC Address dari WiFi Router pada sistem operasi Android 4.x untuk dikombinasikan dengan sistem Absensi berbasis GPS untuk pengembangan Sistem absensi. Penelitian dilakukan dengan menggunakan metode pengembangan sistem dengan Extreme Programming. Hasil dari sistem absensi yang dikembangkan menunjukan bahwa telepon pintar berbasis sistem operasi Android dapat menggunakan dan mengaplikasikan teknologi GPS dan MAC Address agar lokasinya tetap akurat. Keberlanjutan dari sistem ini adalah pengembangan pula fasilitas login sistem yang lebih kredibel contohnya dengan menambahkan fasilitas pemindai data biometrik dari penggunanya.

Kata kunci : sistem absensi mobile, GPS tracking, MAC Address tracking, Rekayasa Perangkat Lunak.

\section{PENDAHULUAN}

Perkembangan teknologi informasi dan komunikasi (TIK) di era globalisasi ini menjadi salah satu hal yang sangat berharga bagi perusahaan atau instansi. Dengan pemanfaatan TIK oleh perusahaan akan membantu organisasi tersebut dalam menangani informasi dalam jumlah besar, bersaing dalam persaingan bisnis.

Pada bagian ini akan menjelaskan latar belakang dari sistem ini dibuat dan juga tinjauan pustaka yang kami gunakan dalam penelitian.

\subsection{Latar Belakang}

Salah satunya sistem informasi yang sering digunakan adalah sistem untuk mengelola informasi sumber daya manusia yang ada di dalam perusahaan. Informasi mengenai sumber daya manusia sangatlah dibutuhkan oleh perusahaan guna menunjang kinerja sumber daya manusia tersebut dan juga menunjang kinerja perusahaan tersebut.

Kendala terjadi bagi perusahaan yang mempunyai tempat kerja pada gedung bertingkat, jika menggunakan absensi hanya berbasiskan GPS (Global Posisition Sistem) (Adikara, 2013), maka GPS tidak akan dapat memberikan lokasi tepatnya dimana karyawan tersebut berada. Melanjutkan penelitian sebelumnya mengenai perancangan sistem absensi berbasis GPS (Adikara, 2013), maka akan dilakukan pengembangan sistem tersebut dengan pemanfaat teknologi lainnya 
Adikara, Pemanfaatan Mac Address Hotspot dalan Pengembangan Sistem Absensi..

sebagai penanda letak dari karyawan tersebut di dalam gedung bertingkat, yaitu menggunakan fasilitas WIFI Router (Hotspot) untuk kemudian mengirimkan MAC Address dari WIFI Router (Hotspot) tersebut. Permasalahan yang akan diselesaikan pada penelitian ini secara umum adalah bagaimana mengembangkan sistem absensi berbasis GPS pada Android versi 4.x dengan menambahkan fungsi pendektesian $M A C$ Address dari WiFi Router (Hotspot) yang terhubung agar dapat meningkatkan keakuratan posisi karyawan atau penggunanya saat menggunakannya.

Sehubung dengan adanya permasalahan pada sistem absensi yang memiliki mobilitas tinggi dan adanya fitur yang disediakan ponsel pintar, kami mengangkat permasalahan ini sebagai topik penelitian dengan judul "Pemanfaatan $M A C$ Adrress WiFi Router (Hotspot) dalam Pengembangan Sistem Absensi Berbasis GPS dan Android ver. 4.x dalam Rangka Meningkatkan Keakuratan Posisi Pengguna”.

\subsection{Tinjuan Pustaka}

Pada bagian ini akan dibahas beberapa pengertian dan tinjuan pustaka dari hal-hal yang berhubungan dengan penelitian yang dijalankan.

\subsubsection{Pengertian Sistem Absensi}

Sistem menurut (Marimin, 2006) adalah suatu kesatuan usaha yang terdiri dari bagian-bagian yang berkaitan satu sama lain yang berusaha mencapai satu tujuan dalam suatu lingkungan kompleks.

Menurut Kamus Besar Bahasa Indonesia, absen adalah tidak masuknya seorang siswa/pegawai pada saat hari masuk/kerja karen sakit, izin, alpa, atau cuti. Sedangkan absensi adalah daftar kehadiran pegawai/siswa, yang berisi jam datang, jam pulang, serta alasan/keterangan kehadiran pegawai.

\subsubsection{Anatomi Android}

Secara sederhana arsitektur Android merupakan sebuah kernel Linux dan sekumpulan pustaka Java dalam suatu framework yang mengatur dan menyediakan alur proses aplikasi (Gambar 1).

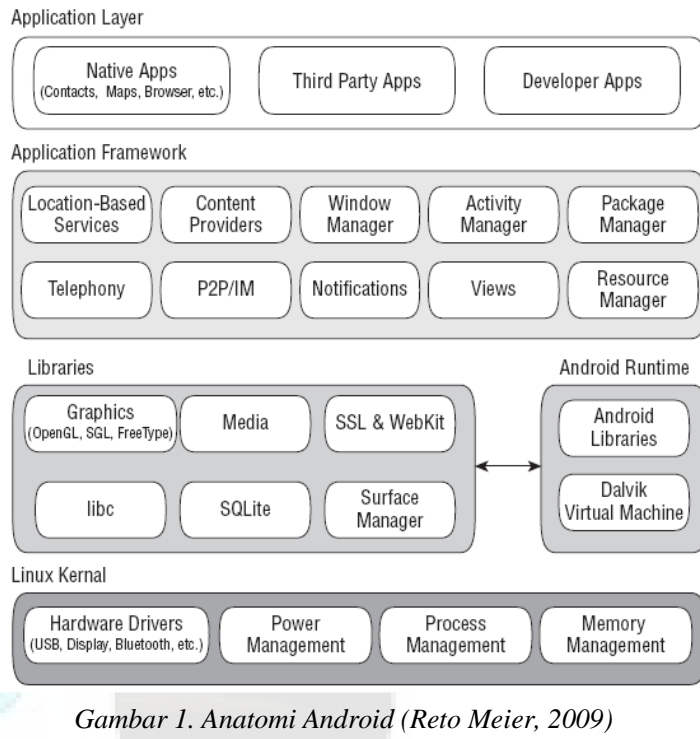

\subsubsection{Global Positioning Sistem (GPS)}

Global Positioning Sistem (GPS) (Greg Millete dan Adam Stroud, 2012) adalah sistem satelit navigasi dan penentuan posisi yang dimiliki dan dikelola oleh Amerika Serikat. Sistem ini didesain untuk memberikan posisi dan kecepatan tigadimensi serta informasi mengenai waktu, secara kontinyu di seluruh dunia tanpa bergantung waktu dan cuaca, bagi banyak orang secara simultan.

\subsubsection{Cara Kerja GPS}

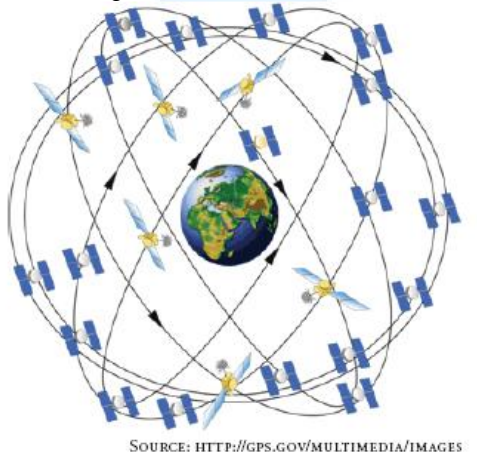

Gambar 2. Cara Kerja GPS

(Greg Millete dan Adam Stroud, 2012)

Menurut (Greg Millete dan Adam Stroud, 2012) Secara umum, penerima GPS menggunakan informasi dari satelit GPS yang mengitari bumi untuk menghitung lokasi pemakai saat ini. Sistem GPS berisi 27 satelit yang terus mengitari bumi, dan mengirimkan informasi ke calon penerima. Setiap satelit mengikuti jalur yang ditetapkan, memastikan bahwa setidaknya empat satelit yang "terlihat" dari setiap titik di bumi pada waktu tertentu. Untuk mampu mendapatkan lokasi, setidaknya empat satelit yang diperlukan untuk menentukan lokasi menggunakan GPS (Gambar 2). 
Jurnal Sistem Informasi, Volume 5, Nomor 4, September 2015, 454-461

\subsubsection{Menentukan Lokasi di Android}

Dalam menentukan lokasi dari perangkat Android, ada beberapa cara yang digunakan dalam memperoleh data tersebut. Cara yang digunakan sebagai berikut :

- GPS Provider, dalam menentukan lokasi dari user Android, perangkat Android langsung terhubung dengan satelit guna memperoleh koordinat dari pemakai. Seperti terlihat pada gambar 4.

- $\quad$ Network Provider, dalam menentukan lokasi dari user Android, ketika perangkat Android tidak bisa terkoneksi dengan satelit, maka secara otomatis, perangkat tersebut akan mencari posisi dari Base Transceiver Station (BTS) dari network provider perangkat android tersebut.

Sebelum terkoneksi dengan GPS provider ataupun network provider, ada beberapa tahap yang dilakukan. Terlihat pada gambar 3 .

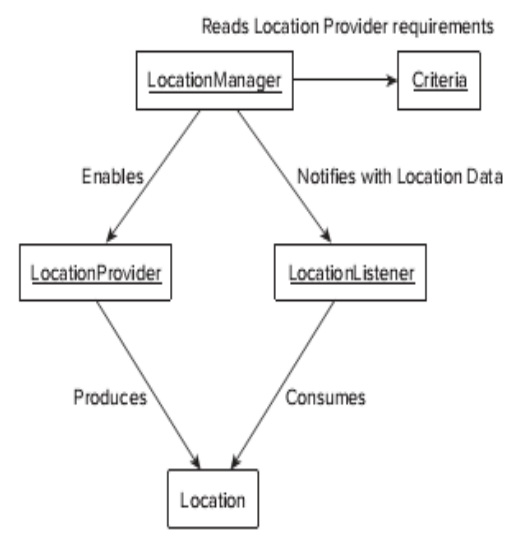

Gambar 3. Android Location Component (Greg Millete dan Adam Stroud, 2012)

\subsubsection{MAC Address}

MAC Address (Media Access Control Address) adalah tanda pengenal yang unik dalam di sebuah network interface untuk berkomunikasi melalui sebuah pemeriksaan pada lapisan jaringan. MAC Address juga merupakan sebuah alamat jaringan yang diimplementasikan pada lapisan data-link dalam tujuh lapisan model OSI, yang merepresentasikan sebuah node tertentu dalam jaringan. Dalam sebuah jaringan berbasis Ethernet, MAC address merupakan alamat yang unik yang memiliki panjang 48-bit (6 byte) yang mengidentifikasikan sebuah komputer, interface dalam sebuah router, atau node lainnya dalam jaringan. MAC Address juga sering disebut sebagai Ethernet address, physical address, atau hardware address.

MAC Address juga mengizinkan perangkatperangkat dalam jaringan agar dapat berkomunikasi antara satu dengan yang lainnya.

\subsubsection{Extreme Programming (XP)}

Extreme Programming (Presman, 2005) merupakan suatu model yang tergolong dalam pendekatan agile yang diusulkan oleh Kent Back. Menurut Presman, definisi XP adalah sebagai berikut: "Extreme Programming (XP) is a lightweight, efficient, low-risk, flexible, predictable, scientific, and fun way to develop software". Model ini cenderung menggunakan pendekatan Object-Oriented.

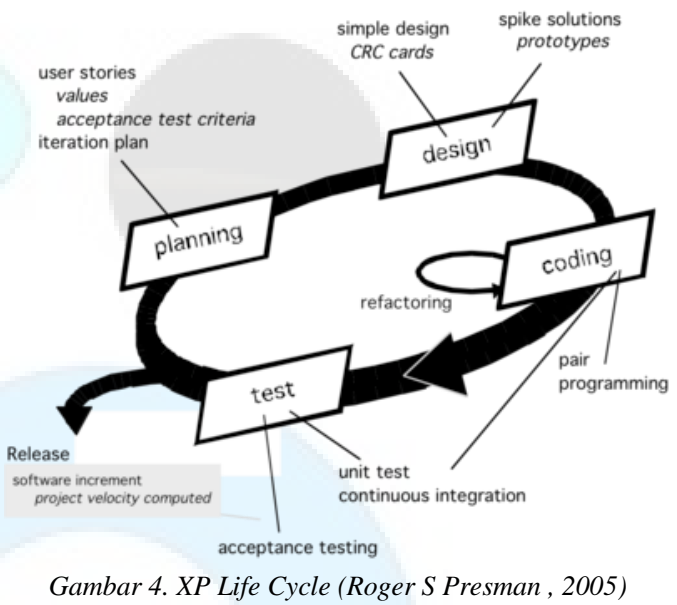

Aktifitas pada XP menurut Roger S. Presman seperti pada Gambar 4 adalah sebagai berikut:

- Aktifitas Perencanaan (Planning)

Pengumpulan user stories dari klien yang klien tetapkan prioritasnya. Setiap story ditetapkan harga dan lama pembangunan. Jika terlalu besar, story dapat dipecah menjadi beberapa story yang lebih kecil. Pada tahap ini juga perlu penentuan nilai dari sistem yang akan dibuat, kriteria penerimaan dari sistem ini, dan rencana iterasi.

- Aktifitas Desain (Design)

Memanfaatkan kartu CRC (ClassResponsibility-Collaborator) untuk identifikasi dan mengatur class di konsep OO. Jika menemui kesulitan, prototype bisa dibangun dan disebut sebagai fase spike solution. Tahap ini juga bisa melakukan refactoring, yaitu mengembangkan desain dari program setelah ditulis

- $\quad$ Aktifitas Pengkodean (Coding)

Menyiapkan unit test sebelum pengkodean dipakai sebagai fokus pemrogram untuk membuat program. Pair programming bisa dilakukan untuk real time program solving dan real time quality assurance.

- Aktifitas Pengujian (Testing)

Menggunakan unit test yang dipersiapkan setelah pengkodean.

\section{METODE PENELITIAN}


Adikara, Pemanfaatan Mac Address Hotspot dalan Pengembangan Sistem Absensi..

Penelitian dilakukan dengan menggunakan metode SWOT untuk analisa masalah dan pengembangan sistem dengan metode Extreme Programming. Penelitian ini akan menganalisis masalah, melakukan perencanaan untuk kemudian di-coding sistemnya. Setelah selesai akan dilakukan pengecekan apakah hasilnya sesuai untuk digunakan sebagai sistem absensi berbasis GPS dengan menggunakan MAC Address.

Untuk pengembangan ini peneliti akan melakukan studi literature untuk mendapatkan cara mengakses GPS digabungkan dengan MAC address, dan survey pada beberapa organisasi yang telah melaksanakan absensi jarak jauh dengan karyawannya yang bersifat bergerak untuk mendapatkan kebutuhan-kebutuhan fungsi dari sistem yang akan dikembangkan. Setelah itu peneliti akan melakukan rancangan (design) menggunakan CRC untuk sistem yang akan dikembangkan untuk kemudian dicoding menggunakan bahasa pemrograman JAVA untuk diujicobakan pada perangkat bersistem operasi Android.

\section{ANALISIS DAN PENEGEMBANGAN}

Analisis masalah dilakukan dengan menggunakan SWOT dan untuk perancangannya akan menggunakan user stories dan Class Responsibility Collaboration.

\subsection{Analisa Masalah}

Dari dilakukanya pengamatan pada proses bisnis sebelumnya dan berdasarkan analisis Usability Testing pada penelitian sebelumnya (Adikara, 2013), maka didapatkan analisa umum dan hasil pengamatan menggunakan Analisis SWOT adalah sebagai berikut:

- Strength / Kekuatan

○ Adanya Fasilitas Wi-Fi yang harus diberdayakan dengan maksimal.

- Mobile berbasis Android saat ini semakin berkembang. Dan banyak masyarakat disekitar kita yang menggunakan mobile berbasis Android, sehingga aplikasi Android memiliki peluang yang cukup bagus untuk dijadikan dasar penerapan aplikasi dimasa mendatang.

- Meningkatnya tingkat penggunaan teknologi informasi sebagai kebutuhan dan gaya hidup.

- Weakness / Kelemahan

- Perpaduan manfaat antara GPS dan MAC Address Wi-Fi yang masih relative sedikit.

- Kegiatan masih dilakukan secara manual sehingga kegiatan menjadi tidak efisien, kurang menarik dan tidak berkembang.

- Aplikasi yang dibuat tidak dapat digunakan dengan Wi-Fi yang menggunakan security proxy server dengan autotentification.

- Aplikasi ini dipasang untuk versi Android minimal Android 3.0 (Honeycomb) atau API 11.

- Titik lokasi yang didapatkan melalui GPS menghasilkan hasil yang kurang tepat apabila Aplikasi digunakan dalam ruang tertutup atau tidak berada dibawah langsung kolong langit, juga dapat dikarenakan sinyal di Indonesia yang masih memiliki keterbatasan.

- Opportunity / Kesempatan

- Belum banyak tersedianya pengembangan aplikasi mobile dengan teknologi MAC Address dalam aplikasi ini sehingga terbukanya kesempatan untuk aplikasi ini dibuat.

- Tersedianya tools gratis yang digunakan dalam pembuatan aplikasi.

- Tersedianya studi pustaka yang bisa digunakan untuk membantu pembuatan aplikasi ini.

- Menggunakan teknologi MAC Address untuk bisa dijadikan dasar pengembangan teknologi mobile dalam lingkup yang luas.

\section{- Threats / Ancaman}

Berkembangnya sistem operasi Android yang diimbangi dengan berkembangnya virus. Semakin banyak virus-virus yang menyerang mobile berbasis Android.

Pemecahan masalah yang diajukan yaitu untuk menyelesaikan masalah berdasarkan analisis SWOT diatas yaitu dengan meningkatkan nilai dari Strength dan Opportunity.

Pemecahan masalahnya adalah dibuatnya suatu Aplikasi berbasis Android sehingga :

- Perpaduan manfaat antara GPS dan MAC Address Wi-Fi dikombinasikan untuk mendapatkan lokasi yang lebih akurat.

- Kegiatan akan dilakukan dengan teknologi informasi terutamanya menggunakan telepon pintar.

- Kegiatan absensi karyawan menjadi lebih terkontrol dan tertata dengan baik.

$\bullet$

\subsection{Pengembangan Sistem}

Sistem dikembangkan menggunakan metode Extreme Programming (XP) mengingat waktu pengerjaan yang sangat singkat dan kebutuhan yang bersifat umum masih bisa berubah-ubah 
Adikara, Pemanfaatan Mac Address Hotspot dalan Pengembangan Sistem Absensi..

ini, diperlukan posisi kantor yang diatur dan disimpan di dalam database. Hal ini bertujuan untuk menjadi parameter pembanding untuk membandingkan posisi karyawan yang akan melakukan kegiatan absensi.

Untuk mengetahui posisi kantor, penulis menggunakan Google Maps, untuk mendapatkan latitude dan longitude dari kantor. Sebagai contoh, penulis menggunakan lokasi Universitas Esa Unggul yang diambil menggunakan Google Maps.

Pada gambar 5 terdapat titik $\mathrm{x}$, titik tersebutlah yang akan di simpan di database oleh admin melalui aplikasi admin. Untuk mengetahui latitude dan longitude dari kantor tersebut, silahkan klik kanan pada titik $\mathrm{x}$ tersebut, maka akan tampil latitude dan longitude dari kantor tersebut.

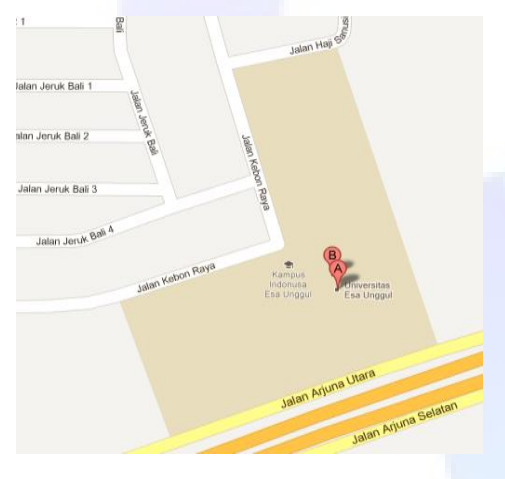

Gambar 5. Lokasi Universitas EsaUnggul

Pada tahap pengujian aplikasi, file installasi apk dikirim ke telepon pintar Android 4.4 untuk kemudian di-install pada telepon pintar tersebut. Jalankan Sistem Absensi untuk masuk ke menu utama (Gambar 6).

Langkah pertama untuk menjalankannya yaitu melakukan pendaftaran (registrasi) telepon pintar dan ID pengguna jika pengguna belum pernah melakukan pendaftaran sebelumnya dengan telepon pintar tersebut (Gambar 7).

Jika sudah terdaftar, maka admin akan memasukan data lengkap sesuai ID yang didaftarkan untuk menetapkan area dimana ID tersebut akan melakukan absensi (Gambar 8, 9). Setalah informasi lengkapnya dipenuhi, penggunakan melakukan proses Check In dan Check Out melalui telepon pintar-nya dengan menyalakan fungsi GPS dan koneksi pada WiFi Hotspot di daerah tersebut dahulu (Gambar 10).

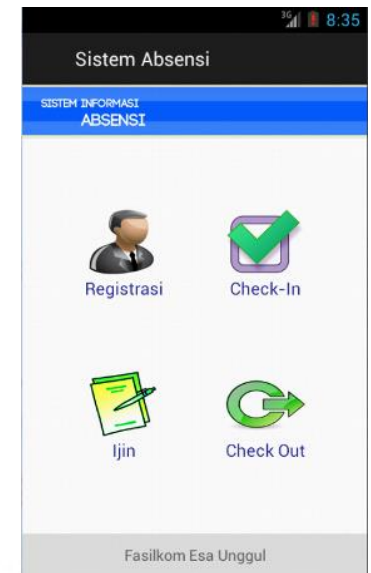

Gambar 6. Tampilan Menu Utama

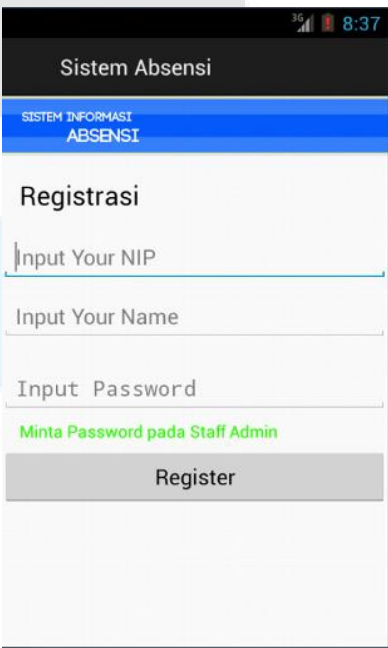

Gambar 7. Pengujian Registrasi

Selama area tempat pengguna melakukan checkin atau check-out masih berada di area yang ditetapkan, maka data akan terekam pada data absensi di hosting data yang telah ditentukan (Gambar 10). Jika diluar area yang diberikan maka data tidak akan pernah masuk ke daftar absensi, sehingga jika saat itu GPS masih memberikan lokasi yang salah, harus terus dicoba sampai masuk dalam area.

\section{DATA KADYAWAN}

\begin{tabular}{|c|c|c|c|c|c|c|c|}
\hline ID & ID Android & Nama & Latitude $\mathrm{K}$ & 1 Latitude Besar & Longitude I & 1 Longitude & \\
\hline 123 & $9774 \mathrm{~d} 56 \mathrm{~d} 682 \mathrm{e} 549 \mathrm{~d}$ & karyawan 1 & $1-6.184737$ & -6.186763 & 106.777608 & 106.778246 & delete edit \\
\hline 123 & $2041 \mathrm{q} 43 \mathrm{t} 135 \mathrm{n} 482 \mathrm{v}$ & karyawan 2 & $2-6.184737$ & -6.186763 & 106.777608 & 106.778246 & delete edit \\
\hline 1236 & $9238 \times 14 \mathrm{f} 423 \mathrm{j} 937 \mathrm{~d}$ & karyawan 3 & $\begin{array}{l}3.184737 \\
\end{array}$ & -6.186763 & 106.777608 & 106.778246 & delete edit \\
\hline 1237 & $1068 \mathrm{~g} 67 \mathrm{k} 598 \mathrm{a} 620 \mathrm{p}$ & karyawan 4 & $\begin{array}{l}4-6.184737 \\
\end{array}$ & -6.186763 & 106.777608 & 106.778246 & delete edit \\
\hline 1238 & $4976 \mathrm{r} 921150 \mathrm{p} 469 \mathrm{z}$ & karyawan 5 & $5-6.184737$ & -6.186763 & 106.777608 & 106.778246 & delete edit \\
\hline
\end{tabular}

Gambar 8. Tampilan Halaman Data Karyawan 


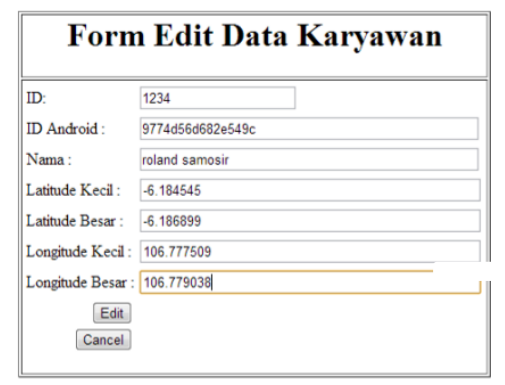

Gambar 9.Tampilan Halaman Edit Karyawan

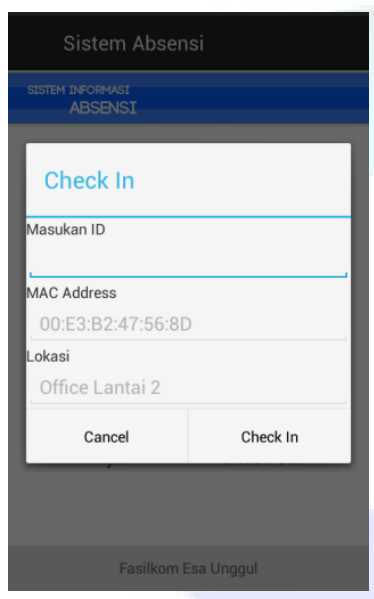

Gambar 10. Pengujian Check-in

Setelah proses check-in dan check-out telah dilakukan, maka keseluruhan proses akan menghasilkan laporan seperti yang digambarkan pada lampiran. Laporan yang dihasilkan tersebut menunjukkan bahwa sistem telah berjalan dengan baik dan memenuhi kriteria penerimaan yang telah didefinisikan pada tahap perencanaan.

\section{SIMPULAN DAN SARAN}

Setelah melakukan proses penelitian dalam merancang dan membangun sistem absensi berbasis GPS dan MAC Address pada Android versi 4.x maka dapa disimpulkan beberapa hal sebagai berikut:

- Telepon pintar berbasis sistem operasi Android dapat menggunakan dan mengaplikasikan teknologi GPS dan MAC Address.

- GPS dan MAC Address mampu memberikan hasil yang saling melengkapi dan berjalan bersama-sama dalam satu aplikasi Android untuk memberikan lokasi yang lebih akurat dan tepat dari seseorang.

- GPS menampilkan hasil posisi yang kurang tepat dikarenakan faktor lokasi dan sinyal oleh penyedia layanan satelite.

- MAC Address mampu menghasilkan informasi SSID sebagai titik lokasi dengan hasil yang tepat.
- $\quad$ Sistem absensi ini mempunyai batasan yaitu hanya bisa dijalankan jika Wi-Fi Hotspot tersedia serta terhubung dengan fasilitas internet.

- Jika terjadi perubahaan mesin Wi-Fi Hotspot maka lokasi dan ID MAC Address pada database harus ikut dirubah agar lokasinya tetap akurat.

Penggunaan GPS dan MAC Address pada aplikasi ini masih dibatasi oleh tidak akuratnya hasil yang didapatkan dengan GPS, batas minimal device Android dengan versi 3.0 dan belum mampu digunakan dalam Wi-Fi dengan security menggunakan http proxy server.

Perlu dikembangkan pula fasilitas login sistem yang lebih kredibel contohnya dengan menambahkan fasilitas pemindai data biometrik dari penggunanya. Dengan adanya fasilitas login yang baik, maka pemakaian dan tujuan absensi menggunakan perangkat mobile ini semakin maksimal terutama di sisi keamanan dan keakuratan data/penggunanya.

Selain itu sistem ini juga masih bisa dikembangkan pada sistem operasi perangkat telepon pintar lainnya seperti iOS, Blackberry dan Windows Phone. Deangan demikian perangkat yang digunakan tidak terbatas pada sistem operasi Android.

\section{DAFTAR RUJUKAN}

Adikara, Fransiskus, 2013 . Analisis dan Perancangan Sistem Absensi Berbasis Global Positioning Sistem (GPS) pada Android ver. 4.x, Prosiding SNTI.

Departemen Pendidikan Nasional, 2008 . Kamus Besar Bahasa Indonesia Pusat Bahasa Edisi Keempat, Jakarta : PT. Gramedia Pustaka Utama.

Elmasri, Ramez dan Shamkant B. Navathe, 2011. Database Sistems Models, Languages, Design and Application Programming Sixth Edition. Massachusetts : Pearson Education Inc.

Marimin, 2006. Sistem Informasi Manajemen Sumber Daya Manusia, Jakarta : Grasindo.

Meier, Reto , 2009. Professional Android Application Development, Indianapolis: Wiley Publishing.

Millete, Greg dan Adam Stroud, 2012. Professional Sensor Android Programming, Indianapolis : John Wiley \& Sons, Inc.

Nazrudin Safaat H. 2012. Pemrograman Aplikasi Mobile Telepon pintar Dan Tablet PC Berbasis Android. Bandung : Informatika

Prabawati, Ari, 2010. Tutorial 5 Hari Membangun GUI dengan Java Netbeans 6.5, 
Adikara, Pemanfaatan Mac Address Hotspot dalan Pengembangan Sistem Absensi..

Yogyakarta : Penerbit Andi.

Pressman , Roger S, 2005. Software Engineering A practitioner's Approach 6th Edition, New York : McGraw - Hill Inc.

Rubin, Jeffrey dan Dana Chisnell, 2008. Handbook of Usability Testing How to Plan, Design, and Conduct Effective Tests, Indianapolis : Wiley Publishing.

Shchildt, Herber, 2005. The Complete Reference Java J2SE 5th Edition",California : Tata McGraw-Hill Publishing.
Thomas M. Connolly, Carolyn E. Begg. 2005. "Database Systems : A Practical Approach to Design, Implementation, and Management", Fourth Edition. Harlow : Pearson Education

Lampiran: Tampilan data absensi karyawan

\begin{tabular}{|c|c|c|c|c|c|c|c|c|c|c|c|c|c|c|}
\hline \multicolumn{6}{|c|}{ Check In } & \multicolumn{9}{|c|}{ Check Out } \\
\hline NIP & Nama & Latitude & Longitude & $\begin{array}{l}\text { Waktu } \\
\text { masuk }\end{array}$ & $\begin{array}{l}\text { MAC Address } \\
\text { masuk }\end{array}$ & $\begin{array}{l}\text { Lokasi } \\
\text { masuk }\end{array}$ & Tanggal & Latitude keluar & $\begin{array}{l}\text { Longitude } \\
\text { keluar }\end{array}$ & $\begin{array}{l}\text { Waktu } \\
\text { keluar }\end{array}$ & $\begin{array}{l}\text { MAC Address } \\
\text { keluar }\end{array}$ & $\begin{array}{l}\text { Lokasi } \\
\text { keluar }\end{array}$ & Tanggal & | Keterangan \\
\hline 1234 & fransis & & & 06:02:00 & & & $\begin{array}{l}2015- \\
05-12 \\
\end{array}$ & & & & & & $\begin{array}{l}2015- \\
05-12 \\
\end{array}$ & ijin \\
\hline 5678 & Adikara & -6.18994916838 & 106.755196506 & $07: 25: 21$ & OO:E3:B2:47:56:8D & \begin{tabular}{|c|} 
Office \\
Lantai \\
1
\end{tabular} & $\begin{array}{l}2015- \\
05-12\end{array}$ & $|-7.29005027949| 2$ & 217.866207617 & 7 14:52:23 & O0:F9:A1:23:88:1C & $\begin{array}{c}\text { Office } \\
\text { Lantai } \\
2\end{array}$ & 2015- & \\
\hline 12345 & Frans & -6.18994916838 & 106.755196506 & $07: 55: 01$ & $00: E 3: B 2: 47: 56: 8 D$ & $\begin{array}{c}\text { Office } \\
\text { Lantai } \\
1 \\
\end{array}$ & $\begin{array}{l}2015- \\
05-12\end{array}$ & $|-7.29005027949| 2$ & 217.866207617 & 7 15:22:33 & 00:F9:A1:23:88:1C & $\begin{array}{c}\text { Office } \\
\text { Lantai } \\
2\end{array}$ & $\begin{array}{l}2015- \\
05-12\end{array}$ & \\
\hline 12345 & Frans & & & 07:02:15 & & & $\begin{array}{l}2015- \\
05-13\end{array}$ & & & & & & $\begin{array}{l}2015- \\
05-13\end{array}$ & sakit \\
\hline
\end{tabular}

